\title{
PENGETAHUAN MAHASIWA CALON GURU PADA PEMBAGIAN PECAHAN
}

\author{
Firman Pangaribuan \\ Prodi Pendidikan Matematika FKIP Universitas HKBP Nommensen \\ Pematangsiantar-Medan \\ Email : firmanpangribfkipuhn@gmail.com
}

\begin{abstract}
ABSTRAK
Penelitian ini bertujuan untuk mengetahui pemahaman mahasiswa calon guru pada pembagian pecahan, dan perubahan pemahamannya pada pembagian pecahan dengan memperkenalkan pemahaman multiplikatif. Subjek penelitian adalah mahasiswa prodi Pendidikan Matematikan FKIP UHN angkatan 2012 sebanyak 40 orang. Jenis penelitian ini adalah deskriptif kuantitatif disertai eksperimen. Hasil penelitian menunjukkan bahwa terdapat peningkatan pemahaman mahasiswa pada pembagian pecahan, pengajuan soal cerita yang menyangkut pembagian pecahan, penyelesaian soal cerita yang menyangkut pembagian pecahan sesudah diperkenalkan pemahaman multiplikatif pada pembagian pecahan dengan menggunakan diagram skematik Vergnaud.
\end{abstract}

Kata kunci: Diagram skematik Vergnaud, Pengetahuan guru, dan Pembagian pecahan

\section{PENDAHULUAN}

Menurut Kurikulum 2006, siswa kelas V SD diharapkan mampu memahami, menjelaskan, serta mengaplikasikan konsep pembagian pecahan. Kurikulum 2013 juga menyatakan bahwa siswa dapat melakukan pembagian pecahan dengan pendekatan ilmiah. Dua rujukan di atas mengharapkan siswa tidak menerima langsung rumus pembagian pecahan, tetapi siswa membangun sendiri pemahaman pembagian pecahan dengan bantuan guru.

Kenyataan di lapangan banyak siswa mengalami kesulitan dalam memahami konsep tersebut dengan baik dan benar. Hasil observasi pada 50 siswa kelas V SD pada 21 Juni 2011 dan pada 24 siswa kelas VII suatu SMP di Pematangsiantar pada 18 Juni 2011, menunjukkan bahwa kebanyakan siswa belum dapat menulis dengan benar rumus pembagian pecahan $\frac{a}{b}: \frac{c}{d}=\frac{a}{b} \times \frac{d}{c}$. Mereka yang belum dapat menulis dengan benar rumus itu, menulis $\frac{a}{b}: \frac{c}{d}=\frac{b}{a} \times \frac{c}{d}$ yaitu mengali invers perkalian pecahan yang dibagi dengan pecahan pembagi dan ada yang menulis $\frac{a}{b}: \frac{c}{d}=\frac{b}{a} \times \frac{d}{c}$ yaitu mengali invers perkalian pecahan yang dibagi dengan invers perkalian pecahan pembagi. Mereka yang dapat menulis dengan benar rumus pembagian pecahan itu tidak dapat menjelaskan mengapa demikian. 


\section{Firman Pangaribuan}

Selanjutnya hasil observasi pada 43 siswa kelas VII dan 51 siswa kelas IX di suatu SMP di Pematangsiantar tanggal 23 Juli 2011 dan pada 35 siswa kelas VIII dan 36 siswa kelas IX di suatu SMP lain di Pematangsiantar tanggal 7 dan 8 September 2011, menunjukkan bahwa kebanyakan siswa dapat menulis dengan benar rumus pembagian pecahan yaitu; $\frac{a}{b}: \frac{c}{d}=\frac{a}{b} \times \frac{d}{c}$ atau $\frac{a}{b}: \frac{c}{d}=\frac{a d}{b d}: \frac{b c}{b d}=$ $a d: b c$ atau $\frac{a}{b}: \frac{c}{d}=\frac{a: c}{b: d}$. Siswa-siswa tersebut dapat menyelesaikan masalah pembagian pecahan yang dinyatakan dalam soal cerita dengan menggunakan rumus pembagian pecahan, tetapi tidak memahami mengapa rumus itu berlaku.

Kesulitan pembagian pecahan bukan hanya pada siswa tetapi juga pada mahasiswa. Kribs-Zaleta (2006) mengatakan orang dewasa pun sukar menjelaskan mengapa algoritma pembagian pecahan yaitu dengan cara mengubah pecahan pembagi menjadi invers perkaliannya kemudian mengalikan dengan pecahan yang dibagi (invert-and-multiply) dapat berlaku. Penelitian Ma (1999) juga menunjukkan bahwa guru di Amerika kesulitan memahami pembagian pecahan. Suatu kasus yang ditemukan Ma, dari 21 orang guru di Amerika yang diminta menghitung $1 \frac{3}{4}: \frac{1}{2}$, hanya 9 orang (43\%) yang melakukan perhitungan dengan betul. Ma menyatakan walau guru itu betul menghitung hasil bagi pecahan itu, ternyata masih gagal dalam membuat soal cerita yang memuat perhitungan itu. Ma juga menemukan bahwa subjek masih belum memahami perbedaan pembagian dengan $\frac{1}{2}$ dan pembagian dengan 2 dan perbedaan pembagian dengan $\frac{1}{2}$ dengan perkalian dengan $\frac{1}{2}$.

Ma (1999) menyatakan bahwa pembagian adalah operasi yang paling kompleks dalam matematika dasar dan pecahan juga merupakan bilangan yang paling kompleks dalam aritmetika. Oleh sebab itu Ma menganggap pembagian pecahan merupakan topik yang paling sulit dalam matematika dasar bagi siswa dan juga bagi guru. Selain itu Kribs-Zaleta (2006); Rizvi \& Lawson (2007); Orill \& Jacobson (2010); Sharp \& Adam (2002); Bulgar (2009) mengemukakan bahwa pembagian pecahan adalah konsep yang sulit bagi siswa dan juga bagi guru. Kesulitan siswa memahami konsep pembagian pecahan dan keterbatasan guru membangun konsep pembagian pecahan, mengakibatkan guru hanya melakukan transfer pengetahuan yang sudah jadi dalam pelaksanaan pembelajaran di kelas. 


\section{Pengetahuan Mahasiwa Calon Guru Pada Pembagian Pecahan}

Siswa akan sulit membangun pengetahuannya apabila guru tidak mempunyai pemahaman yang kokoh pada konsep itu. Untuk mengurangi keterbatasan guru memahami konsep pembagian pecahan, perlu dilakukan studi bagaimana pengetahuan mahasiswa calon guru memahami pembagian pecahan dan konstruksi pemahaman konsep itu sebelum dia diluluskan menjadi guru.

Pada bagian pengantar Standar Kompetensi bidang studi matematika kurikulum 2006, dinyatakan bahwa "Dalam setiap kesempatan, pembelajaran matematika hendaknya dimulai dengan pengenalan masalah yang sesuai dengan situasi (contextual problem). Dengan mengajukan masalah kontekstual, peserta didik secara bertahap dibimbing untuk menguasai konsep matematika". Dengan demikian guru harus dapat mengajukan atau membangun soal cerita yang menyangkut konsep pembagian pecahan. Penggunaan soal cerita pada pembelajaran, siswa akan dibimbing menemukan konsep pembagian pecahan. Akan tetapi mengajukan soal cerita untuk membangun suatu konsep pembagian pecahan akan menjadi sulit jika konsep itu belum dipahami. Berdasarkan uraian itu, mahasiswa calon guru yang akan menjadi guru, perlu diketahui bagaimana kesiapan mereka memahami pembagian pecahan sekaligus kemampuannya membangun soal cerita yang menyangkut pembagian pecahan maupun mengaitkan masalah kontekstual yang menyangkut pembagian pecahan.

Beberapa model pembagian bilangan bulat yang digunakan sebagai model pembagian pecahan dikenal dengan dua jenis yakni pembagian pengukuran (measurement) dan pembagian partitif (partitive) (Rizvi dan Lawson; 2007). Pembagian pengukuran adalah membagi keseluruhan dengan banyak unsur dalam setiap kelompok untuk memperoleh banyak kelompok. Sebagai contoh $I b u$ mempunyai 12 tangkai bunga dan akan dimasukkan ke dalam beberapa pot dan setiap pot memuat 4 tangkai. Tentukanlah banyaknya pot. Dari contoh itu, total semua unsur adalah 12, banyak unsur setiap grup (banyak bunga setiap pot) adalah 4, dan akan ditentukan banyak grup (pot). Bulgar (2009) mengatakan model pembagian quotitive ini sejalan dengan pengurangan berulang, karena mengurangi 4 secara berulang dari 12 hingga habis. Cramer dkk (2010) menyatakan pada awal pembelajaran pembagian pecahan lebih cocok menggunakan pengurangan berulang, karena mengurangkan pecahan berpenyebut sama dan pengurangan 


\section{Firman Pangaribuan}

maupun penjumlahan pecahan yang berpenyebut sama telah dipelajari sebelumnya. Tetapi menggunakan model ini akan sulit apabila digunakan pada pembagian pecahan yang pembaginya lebih dari bilangan yang dibagi seperti $\frac{1}{5}: \frac{1}{3}$. Jika model ini digunakan untuk pembagian pecahan yang berpenyebut sama, walaupun dengan pembagi kurang dari bilangan yang dibagi masih akan ditemukan kesulitan jika hasil baginya bukan bilangan bulat. Zembat (2004) menemukan bahwa kesulitan siswa pada pembagian pecahan itu karena subjeknya belum bisa menghubungkan keterkaitan tiga kuantitas, yaitu kuantitas pecahan pembagi, bilangan yang dibagi dan sisa hasil bagi.

Model partitif merupakan pembagian yang diketahui banyak unsur keseluruhan dan banyak kelompok, dan akan ditentukan banyak unsur setiap kelompok. Rizvi dan Lawson (2007) menyebut pembagian partitif ini merupakan berbagi secara adil (fair sharing). Contoh dalam bilangan bulat, ibu mempunyai 12 tangkai bunga akan dimasukkan ke dalam 3 buah pot. Tentukan berapa tangkai bunga dalam setiap pot. Setiap pot memuat tangkai bunga sama banyak. Banyak bunga akan dibagi sama banyak dalam setiap pot. Kesulitan menggunakan model ini pada pembagian pecahan jika pembaginya sebagai pecahan. Misalnya $12: \frac{1}{3}$ dengan soal 12 tangkai bunga dalam $\frac{1}{3}$ pot akan tidak berarti.

Untuk menghindari kesulitan memahami pembagian pecahan dengan menggunakan model pembagian pengukuran maupun partitif, Vergnaud (dalam Rizvi dan Lawson, 2007) membuat suatu skema yang menggunakan konsep proporsional. Hubungan proporsional adalah kesamaan dua rasio atau laju (rate). Rasio adalah hubungan multiplikatif antara dua kuantitas dengan satuan yang sama. Laju adalah hubungan multiplikatif antara dua kuantitas dengan satuan yang berbeda. Pada skema Vergnaud ini siswa perlu menyadari hubungan multiplikatif antara kuantitas bilangan yang dibagi dan pembagi. Squire dan Bryant (dalam Downton, 2013) mengatakan siswa perlu menyadari pemahaman konseptual pada hubungan perkalian yang melekat dalam masalah pembagian. Sebagai contoh pada pembagian $12: 4$ dipandang sebagai 2 buah kuantitas, yakni 12 sebagai kuantitas pertama dan 4 sebagai kuantitas kedua. Hasil bagi itu dipandang sebagai suatu kuantitas jika kuantitas pertama 4 menjadi 1, maka yang dicari perubahan kuantitas 


\section{Pengetahuan Mahasiwa Calon Guru Pada Pembagian Pecahan}

kedua 12 menjadi kuantitas tertentu dengan rasio kedua pecahan adalah sama. Kesamaan rasio itu menjadi $\frac{12}{4}=\frac{\cdots}{1}$.

Model pembagian pengukuran atau partitif dengan masing-masing contoh soal di atas dapat dinyatakan degan skema Vergnaud sebagai berikut.

Tabel 1 Model Pengukuran (pengurangan berulang)

Ibu mempunyai 12 tangkai bunga dan akan dimasukkan ke dalam beberapa pot dan setiap pot memuat 4 tangkai. Tentukanlah banyaknya pot.

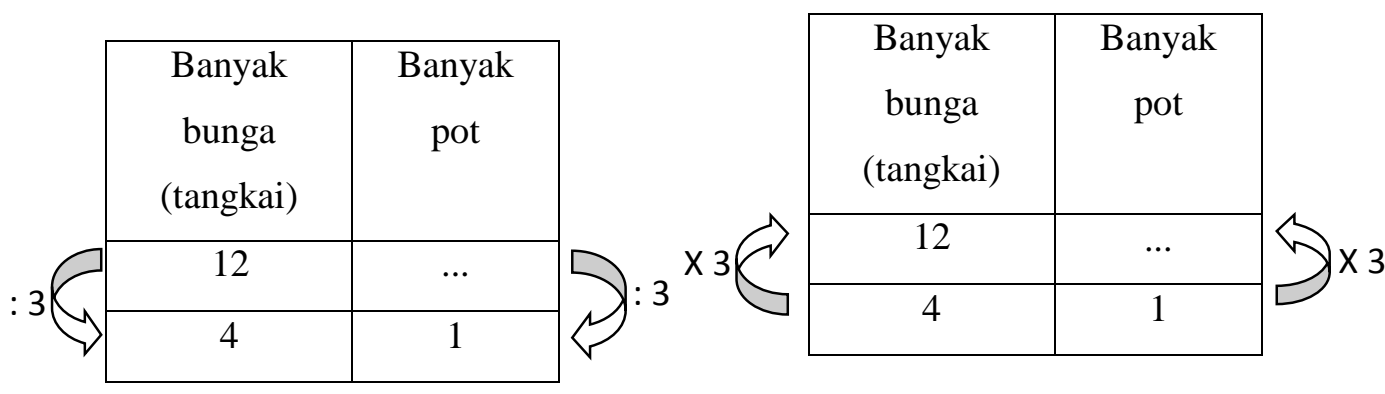

Tabel 2 Model Partitif (pembagian secara adil)

Ibu mempunyai 12 tangkai bunga akan dimasukkan ke dalam 3 buah pot. Tentukan berapa tangkai bunga dalam setiap pot. Setiap pot memuat bunga sama banyak.

\begin{tabular}{|c|c|}
\hline Banyak bunga (tangkai) & Banyak pot \\
\hline 12 & 3 \\
\hline$\ldots$ & 1 \\
\hline
\end{tabular}

Pada Tabel 1 sebagai model pengukuran, banyak bunga 12 tangkai (baris 2 kolom 1) mempunyai hubungan multiplikatif dengan banyak bunga 4 tangkai (baris 3 kolom 1) yaitu kelipatan 3. Demikian juga untuk bilangan kolom 2 menggunakan kelipatan 3. Penalaran itu diperoleh dengan mengubah susunan kalimat dengan semantik yang sama, yaitu dalam satu pot ada 4 tangkai bunga, maka dalam berapa pot terdapat 12 tangkai bunga. Jika seseorang kesulitan melihat perubahan dari 12 menjadi 4, dapat diubah menjadi perubahan dari 4 menjadi 12 dengan mengalikan 3 dan akan diperoleh dari 1 pot menjadi 3 pot. Demikian juga untuk memperoleh hasil bagi dengan memperhatikan model partitif yang sudah diubah menjadi diagram skematik, dengan menggunakan penalaran proporsional akan ditemukan bilangan yang dicari. Hal penting yang dituntut pada skema itu kemampuan 


\section{Firman Pangaribuan}

menyajikan soal pembagian dalam logika penempatan kuantitas yang diketahui dan dicari sesuai dengan kuantitas yang diberikan.

Dua tabel di atas menguraikan pembagian bilangan asli menggunakan diagram skematik Vergnaud. Berikut ini menunjukkan penggunaan skema itu untuk pembagian pecahan model partitif dengan contoh soal konteks mengecat "Tuti mengecat suatu dinding seluas $\frac{4}{5} \mathrm{~m}^{2}$ dengan cat sebanyak $\frac{2}{3}$ desi liter. Jika cat yang tersedia 1 desi liter, tentukan luas dinding yang kena cat". Tabel berikut ini sebagai skema pencarian suatu bilangan sedemikian hingga dengan hubungan kuantitas $\frac{2}{3}$ dengan $\frac{4}{5}$ mempunyai hubungan multiplikatif yang sama dengan bilangan 1 dan bilangan yang dicari. Untuk memperoleh hasil bagi pecahan dengan skema Vergnaud disajikan pada Tabel 3.

Alternatif lain menghitung luas dinding yang kena cat dengan cat tersedia 2 desi liter kemudian dihitung luas dinding yang kena cat dengan cat yang tersedia 1 desi liter. Sehingga luas dinding yang kena cat dengan cat yang tersedia 1 desi liter adalah $\frac{4}{5} \times 3: 2 \mathrm{~m}^{2}$. Secara umum prosedur menghitung pembagian pecahan dengan pecahan dengan konteks partitif itu didapat $\frac{b}{a}: \frac{d}{c}=\frac{b}{a}: d \times c$ atau $\frac{b}{a}: \frac{d}{c}=\frac{b}{a} \times c: d$

Tabel 3 Skema Vergnaud pembagian pecahan

\begin{tabular}{|c|c|}
\hline Banyak cat $(d l)$ & Luas dinding yang kena cat $\left(\mathrm{m}^{2}\right)$ \\
\hline$\frac{2}{3}$ & $\frac{4}{5}$ \\
\hline 1 & $\ldots$ \\
\hline$\frac{2}{3}: 2=\frac{1}{3}$ & $\frac{4}{5}: 2$ \\
\hline$\frac{1}{3} \times 3=1$ & $\frac{4}{5}: 2 \times 3$ \\
\hline
\end{tabular}

Suatu alternatif memperoleh jawabannya dengan keterbatasan pada simbol formal agar langsung menyusun diagram skematik, dapat lebih dahulu menggambarkan masalah pembagian itu sesuai konteksnya sebagai berikut.

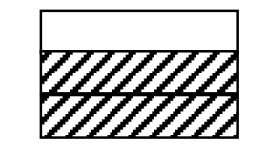

Cat tersedia $\frac{2}{3} \mathrm{dl}$

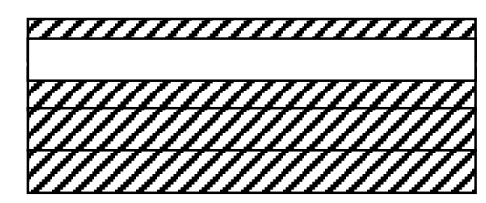

Luas dinding kena cat $\frac{4}{5} \mathrm{~m}^{2}$

Gambar 1 Perbandingan cat yang tersedia dengan luas dinding yang kena cat 
Menggunakan cat $(2 / 3: 2) \mathrm{dl}=1 / 3 \mathrm{dl}$ diperoleh luas dinding yang kena cat $(4 / 5: 2)$ $\mathrm{m}^{2}=2 / 5 \mathrm{~m}^{2}$ dengan bantuan gambar. Menggunakan cat $1 \mathrm{dl}$ diperoleh luas dinding yang kena cat $4 / 5: 2 \times 3 \mathrm{~m}^{2}=2 / 5 \mathrm{~m}^{2} \times 3=6 / 5 \mathrm{~m}^{2}$.

Pangaribuan (2015) menemukan siswa kelas V SD mampu bernalar proporsional pada pembagian pecahan melalui wawancara dengan menyelesaikan soal “Ibu berencana membuat roti bolu yang terbuat dari terigu dan bahan lainnya. Untuk membuat 1 loyang roti bolu diperlukan $1 / 3 \mathrm{~kg}$ terigu. Berapa loyang roti bolu yang dapat dibuat dengan menghabiskan terigu yang tersedia?" Siswa itu menguraikan pembagian itu menjadi dua jenis pembagian yakni $1: 1 / 3$ dan $1 / 2: 1 / 3$. Untuk memperoleh banyak roti bolu yang terbuat dari $1 \mathrm{~kg}$ terigu, siswa itu dengan mudah menjawab 3 loyang bolu dengan alasan 3 kali 1/3 sama dengan 1 . Selanjutnya untuk memperoleh banyak roti bolu yang dapat dibuat dari $1 / 2 \mathrm{~kg}$ terigu, siswa itu menyebut jika tepung terigu $1 \mathrm{~kg}$ menjadi 3 loyang bolu, berarti jika tepung terigu $1 / 2 \mathrm{~kg}$ diperoleh $1 \frac{1}{2} 2$ loyang bolu dengan alasan 1 menjadi $1 / 2$ dan 3 menjadi 1 1/2. Pandangan siswa ini menunjukkan bahwa penalaran proporsional digunakannya menyelesaikan masalah pembagian itu. Walaupun siswa itu tidak menggambarkan diagram skematiknya, tetapi hakekat dari diagram skematik Vergnaud terungkap dari pemikiran siwa itu.

Sellke, Behr dan Voelker (dalam Rizvi dan Lawson; 2007) menunjukkan siswa kelas 7 dapat menggunakan diagram skematik Vergnaud dalam pembagian pecahan. Rizvi dan Lawson (2007) sudah melakukan penelitian dengan subjek guru praktek bahwa mereka dapat memahami pembagian pecahan dengan menggunakan diagram skematik Vergnaud. Penulis belum menemukan bukti bahwa mahasiswa calon guru matematika di FKIP UHN dapat memahami pembagian pecahan dengan bantuan menggunakan diagram skematik Vergnaud.

Berdasarkan uraian di atas pertanyaan penelitian dinyatakan sebagai berikut.

1. Bagaimana pemahaman mahasiswa calon guru pada pembagian pecahan?

2. Bagaimana perubahan pemahaman mahasiswa calon guru pada pembagian pecahan setelah diperkenalkan pemahaman multiplikatif melalui diagram skematik Vergnaud? 


\section{Firman Pangaribuan}

\section{METODE PENELITIAN}

Sesuai dengan pertanyaan penelitian, pendekatan penelitian ini adalah deskriptif berdasarkan data yang diperoleh dari instrumen bentuk tes uraian dan diolah menjadi data kuantitatif. Khusus untuk menjawab pertanyaan no 2, menggunakan rancangan penelitian eksperimen bentuk Pretes-Postes kelompok tunggal (the one group pretest-postest design) (Siswono, 2010). Sehingga penelitian ini menggunakan pendekatan deskriptif kuantitatif.

Subjek penelitian ini adalah mahasiswa prodi Pendidikan Matematikan FKIP UHN angkatan 2012 sebanyak 40 orang dengan 32 wanita dan 8 pria. Tujuan penelitian yang pertama, untuk mengetahui model pembagian yang dikenali subjek dan hambatan yang dialami dalam mengajukan soal cerita pembagian. Atas dasar itu diperlukan instrumen bantu bentuk tes menyelesaikan soal pembagian bilangan bulat dan asli dengan meminta berbagai interpretasi yang mungkin untuk menyelesaikannya dan meminta subjek mengajukan soal cerita berdasarkan soal pembagian yang diberikan. Soal menghitung pembagian dikelasifikasi atas: pembagian bilangan bulat, pecahan dibagi bilangan bulat, bilangan bulat dibagi pecahan, pecahan dibagi pecahan dengan pembagi lebih dari yang dibagi, pecahan dibagi pecahan dengan pembagi kurang dari yang dibagi.

Tujuan penelitian ini, untuk mengetahui apakah subjek memahami penalaran proporsional sebagai masalah pembagian. Penalaran proporsional itu diamati melalui masalah rasio atau rate. Atas dasar itu diperlukan instrumen tes pembagian menyangkut penalaran aditif (penjumlahan) dan penalaran multiplikatif. Pada bagian ini diidentifikasi apakah subjek dapat mengenali soal sebagai hubungan antarkuantitas secara aditif dan soal sebagai hubungan antarkuantitas secara multiplikatif. Sesuai dengan tujuan penelitian yang ketiga yakni akan diawali dengan bantuan pelaksanaan pembelajaran, perlu mengetahui lebih cermat hambatan dalam memahami penalaran proporsional yaitu melalui hubungan multiplikatif atau hanya sebatas hubungan aditif.

Sesuai tujuan penelitian kedua, semua subjek diberikan pembelajaran pemahaman pembagian dalam bentuk rasio antara pembagi dan bilangan yang dibagi, yang dikaitkan dengan pembagian. Pada situasi itu subjek dibimbing 


\section{Pengetahuan Mahasiwa Calon Guru Pada Pembagian Pecahan}

menemukan hubungan multiplikatif antara bilangan pembagi, yang dibagi, dan hasil bagi. Pada pembelajaran ini dikenalkan diagram skematik Vergnaud untuk menyelesaikan pembagian bilangan bulat yang menghubungkan penalaran proporsional dengan pembagian pecahan. Selanjutnya membimbing subjek menemukan hubungan konsep rasio dengan pembagian pecahan, yakni menghubungkan penalaran proporsional sebagai masalah pembagian pecahan. Setelah selesai pembelajaran, subjek kembali diberi tes yang sama ketika menjawab tujuan penelitian nomor 1 , untuk mengetahui perubahan pemahaman pembagian pada subjek.

Instrumen yang digunakan adalah adaptasi instrumen yang disusun oleh Rizvy dan Lawson (2007). Aktivitas adaptasi instrumen (lembar tugas) ini menerjemahkan ke bahasa Indonesia dari bahasa asing, dengan menyesuaikan pada sosial budaya lingkungan. Validasi keterbacaan dan isi dilakukan secara empiris kepada mahasiswa prodi pendidikan matematika yang bukan subjek penelitian dan hasil validasi menunjukkan bahwa instrumen dapat dipahami dan tujuan soal dapat dimengerti (instrumen terlampir).

\section{HASIL PENELITIAN DAN PEMBAHASAN}

\section{Pemahaman pembagian}

Pemahaman subjek pada pembagian diperoleh berdasarkan instrumen butir 1a. Pembagian itu diuraikan atas: a) pembagian bilangan asli dengan bilangan asli, b) pembagian bilangan asli dengan pecahan biasa, c) pembagian pecahan biasa dengan bilangan asli, d) pembagian pecahan biasa dengan pecahan biasa dan e) pembagian pecahan campuran dengan pecahan biasa. a) Pemahaman pembagian bilangan asli dengan bilangan asli masih digolongkan atas hasil bagi sebagai bilangan bulat dan hasil bagi sebagai pecahan. Pemahaman pembagian bilangan asli dengan bilangan asli dengan hasil bagi sebagai bilangan bulat berdasarkan jawaban subjek pada instrumen butir 1a(i) dan $1 \mathrm{~b}$ (ii) yakni pemahaman mereka pada pembagian 108:4, hanya $15 \%$ (6 orang dari 40 orang) yang dapat menjawab benar dengan pemahaman pembagian sebagai pengurangan berulang, dan sebagai partitif. Skor rata-rata pembagian ini adalah 4,5 pada rentang 0 sd 10 . Selainnya 


\section{Firman Pangaribuan}

menggunakan pembagian "bentuk panjang" atau "bagi kurung" yang justru menggunakan algoritma yang lebih rumit, dan belum tentu dipahami mengapa demikian algoritma itu. Pemahaman subjek pada pembagian bilangan asli dengan bilangan asli dengan hasil bagi sebagai pecahan, didasarkan data oleh jawaban siswa pada butir $1 \mathrm{a}(\mathrm{vi})$ dan $1 \mathrm{~b}(\mathrm{vi})$. Tidak seorang pun yang dapat menguraikan mengapa 5:7 menjadi 5/7 walaupun diminta dengan gambar. Subjek hanya menulis 5:7 = 5/7 tanpa alasan. Berdasarkan skor yang diberikan pada jawabannya subjek mempunyai skor rata-rata 1,65 dari rentang 0 sd 10.

Pemahaman subjek pada pembagian pecahan biasa dengan bilangan asli diperoleh melalui jawaban subjek pada butir 1a(ii) yaitu $\frac{1}{2}: 3$. Jawaban subjek hanya 1 orang menjawab benar, dan rata-rata skor yang diperoleh adalah 3,675 . c) Pembagian bilangan asli dengan pecahan diperoleh melalui jawaban subjek pada butir $1 \mathrm{a}(\mathrm{v})$ yaitu $4: \frac{1}{3}$. Jawaban subjek hanya 1 orang menjawab benar, dan ratarata skor yang diperoleh adalah 2,65. d) Pembagian pecahan biasa dengan pecahan biasa terdiri atas pembagi kurang dari bilangan yang dibagi. Pembagian ini digolongkan lagi atas hasil bagi sebagai bilangan asli dan hasil bagi sebagai pecahan. Pembagian pecahan biasa dengan pecahan biasa dengan pembagi kurang dari penyebut dan hasil bagi sebagai bilangan bulat diperoleh data melalui jawaban subjek pada butir 1a(iii) yakni $\frac{1}{2}: \frac{1}{4}$. Jawaban subjek hanya 1 orang yang menjawab benar dengan rata-rata skor 2,75. Sedangkan sebagai hasil bagi sebagai pecahan diperoleh jawaban subjek pada butir la(iv) yaitu $\frac{1}{3}: \frac{1}{5}$ dan tidak ada subjek yang menjawab benar. Skor rata-rata subjek pada butir ini sebesar 1,75. Pembagian pecahan biasa dengan pecahan biasa dengan pembagi lebih dari bilangan yang dibagi dan hasil bagi sebagai pecahan, diperoleh dari jawaban subjek pada butir 1a(vii) yaitu $\frac{1}{4}: \frac{1}{2}$ dan butir $1 \mathrm{a}$ (viii) $\frac{1}{4}: \frac{1}{2}$. Kedua pembagian ini tidak seorang pun subjek menjawab benar. Rata-rata skor dari kedua butir ini berturutturut adalah 1,625 dan 1,4. e) Kemudian untuk pembagian pecahan campuran dengan pecahanbiasa diperoleh dari jawaban subjek pada butir $1 \mathrm{a}$ (ix) yaitu $1 \frac{1}{2}: \frac{1}{3}$. Tidak seorang pun subjek menjawab benar pemahaman dari pembagian ini, dan 


\section{Pengetahuan Mahasiwa Calon Guru Pada Pembagian Pecahan}

rata-rata skor dari butir ini adalah 1,075. Secara umum gambaran rata-rata skor setiap butir ini disajikan pada tabel 6 bagian Pretes.

Berdasarkan Tabel 6 yang menyangkut rata-rata skor pemahaman subjek pada pembagian, tampak bahwa urutan kesulitan jenis pembagian mulai dari ratarata skor yang paling kecil hingga paling besar. Pemahaman yang paling sulit adalah pembagian pecahan campuran dengan pecahan biasa yaitu butir 1a(ix), kemudian pembagian pecahan biasa dengan pecahan biasa dengan bilangan yang dibagi kurang dari pembagi yaitu butir 1a(vii) dan 1a(viii). Pembagian bilangan asli dengan bilangan asli dengan hasil bagi sebagai pecahan yakni butir 1a(vi) juga tidak dipahami oleh subjek. Tampaknya subjek hanya menganggapnya sebagai suatu kesepakatan dengan tanpa memberi argumen mengapa 5:7 menjadi 5/7. Berdasarkan rata-rata skor itu jika diurutkan jenis pembagian menurut tingkat kesulitan berturut-turut adalah $1 \frac{1 / 2}{2}: 1 / 3,1 / 5: 1 / 2,1 / 4: 1 / 2,5: 7,1 / 3: 1 / 5,4: 1 / 3$, $1 / 2: 1 / 4,1 / 2: 3$, dan $108: 4$.

Untuk mengontrol bagaimana pemahaman subjek pada pembagian untuk butir 1a(i) sd 1a(ix), subjek diminta kembali menjawab butir 1a(i) sd 1a(ix) melalui butir 1c (i) sd 1c(ix). Respons subjek menunjukkan 87,5\% (35 orang) menjawab sebagai penerapan rumus yaitu menggunakan 'invert and multiply' dan 5 orang tidak memberi jawaban. Jawaban pembagian pecahan ini menunjukkan indikasi bahwa subjek dapat melakukan pembagian pecahan secara mekanistis saja.

\section{Kemampuan mengajukan soal cerita pada pembagian}

Pemahaman pembagian terkait dengan kemampuan subjek mengajukan soal pembagian dalam bentuk cerita. Sebagai contoh soal untuk mengajukan soal cerita pada pembagian bilangan bulat adalah sebagai berikut. Tulis soal cerita untuk pembagian 108:4. Rata-rata skor kemampuan mengajukan soal cerita sesuai dengan bentuk pembagian disajikan dalam Tabel 7 pada baris Pretes. Berdasarkan rata-rata skor pada Tabel 7 bahwa pengajuan soal yang dapat dilakukan siswa adalah membuat soal cerita dengan model 108:4 yakni butir soal 1d(i), yaitu skor 8,075. Pengajuan soal cerita dengan model pembagian bilangan asli 5:7 ternyata lebih sukar dari pada pembagian pecahan $1 / 2: 3$. Hal ini ditunjukkan rata-rata skor $1 / 2: 3$ 


\section{Firman Pangaribuan}

yakni 5,58 pada butir soal $1 \mathrm{~d}(\mathrm{iii})$ lebih tinggi dari pada rata-rata skor 5:7 yakni 3,5 pada butir soal $1 \mathrm{~d}(\mathrm{vi})$. Pengajuan soal cerita dengan model matematika pembagian pecahan tampak bahwa subjek masih belum memahaminya.

Kuatnya hubungan pemahaman subjek pada pembagian dengan kemampuan mengajukan soal cerita pada pembagian, ditunjukkan dengan korelasi rata-rata skor kedua variabel itu. Nilai korelasi yang diperoleh adalah 0,675 , yang berarti jika pemahaman pada pembagian belum baik, maka kemampuan mengajukan soal cerita juga akan terhambat. Pada tabel ini tampak bahwa pengajuan soal pembagian bilangan asli dengan bilangan asli masih baik, yakni $80 \%$ subjek dapat mengajukan soal cerita dengan baik. Sebaliknya subjek mengalami kesulitan mengajukan soal cerita pembagian pecahan. Pengajuan soal cerita untuk pembagian pecahan dengan bilangan asli, yaitu $\frac{1}{2}: 3$ masih dapat dibuat oleh 21 subjek (52,5\%). Setelah diperiksa soal yang diajukan subjek adalah bentuk pembagian partitif, karena akan sulit membuat soal dalam bentuk pengurangan berulang. Kesulitan mengajukan soal dalam pengurangan berulang karena bilangan yang dibagi kurang dari pembagi.

\section{Kemampuan menyelesaikan soal cerita}

Kemampuan subjek menyelesaikan soal cerita pembagian untuk pembagian bilangan asli adalah melalui data jawaban subjek pada soal $2 \mathrm{a}$ dan $2 \mathrm{~b}$ dengan konteks menghitung gaji adalah baik, yakni rata-rata skor 8,5. Kemampuan menyelesaikan soal cerita menyangkut pembagian pecahan dengan pecahan khususnya menyangkut pecahan satuan 1/2, 1/4, dan $1 / 3$ tidak semudah menyelesaikan pembagian bilangan asli. Pembagian menyangkut pecahan ini mempunyai rata-rata skor 6 . Skor ini diperoleh melalui data jawaban subjek pada soal 3a, 3b, 4a, dan 4b. Kemampuan menyelesaikan soal cerita menyangkut pecahan campuran bagi pecahan campuran melalui jawaban subjek pada soal no 5a dan 5 b sangat lemah sekali yaitu rata-rata skor 3,1. Kemampuan menyelesaikan soal cerita menyangkut pembagian bilangan asli dengan konteks kecepatan, waktu, dan jarak melalui data pada jawaban subjek pada soal no 6a, 6b, dan $6 \mathrm{c}$ adalah baik, yakni rata-rata skor 6,5. Kemampuan menyelesaikan soal cerita menyangkut 


\section{Pengetahuan Mahasiwa Calon Guru Pada Pembagian Pecahan}

pembagian pecahan nonunit dengan bilangan bulat melalui data pada jawaban subjek pada soal no 7,8 , dan 9 adalah termasuk sulit yaitu rata-rata skor 3,7. Kemampuan menyelesaikan soal cerita tentang penjumlahan atau pengurangan dalam konteks perbandingan usia dan deret, melalui data pada jawaban subjek pada soal no 10, 11, dan 13 adalah sangat kesulitan sekali, hingga mencapai rata-rata skor 1,4 . Bagi subjek yang memberi jawaban, mereka melakukan pembagian atau perkalian yang seharusnya penjumlahan atau pengurangan. Kemampuan menyelesaikan soal cerita menyangkut perbandingan berbalik nilai, melalui data jawaban subjek pada soal no. 12 dan 16, diperoleh rata-rata skor 1,1. Kemampuan subjek dalam perbandingan terbalik ini sangat lemah juga. Ringkasan kemampuan subjek menyelesaikan soal cerita disajikan pada Tabel 7 bagian Pretes.

Berdasarkan Tabel 7, pemahaman subjek yang paling lemah adalah pada perbandingan berbalik nilai, sementara penguasaan yang lebih baik pada pembagian bilangan asli konteks gaji. Pembagian bilangan asli dengan konteks kecepatan, waktu, dan jarak masih lebih sulit dibandingkan dengan konteks gaji. Hal ini kemungkinan konteks gaji masih lebih konkret dari pada konteks kecepatan, atau konteks kecepatan masih lebih abstrak dari pada konteks gaji. Pada pembagian pecahan, pembagian pecahan satuan lebih baik pemahaman subjek dari pada pembagian menyangkut pecahan campuran maupun pecanan non satuan. Hal ini kemungkinan disebabkan subjek lebih akrap pemahamannya pada pecahan satuan seperti $1 / 2,1 / 4$, dan $1 / 3$. Pemahaman subjek pada penjumlahan dengan diselesaikan dengan perkalian, kemungkinan pemahamannya pada soal cerita tidak tuntas.

\section{Pemahaman pembagian setelah diperkenalkan diagram skematik Vergnaud}

Pemahaman subjek pada pembagian setelah dilakukan pembelajaran pembagian dengan menggunakan diagram skematik Vergnaud, dilakukan kembali tes dengan tes yang sama seperti tes sebelum diberikan pembelajaran. Hasil pemahaman subjek untuk pembagian sebelum dan sesudah diberikan pembelajaran untuk pemahaman pembagian disajikan pada Tabel 5 berikut. 


\section{Firman Pangaribuan}

Tabel 5: Skor Pretes dan Postes pemahaman pembagian

\begin{tabular}{|c|c|c|c|c|c|c|c|c|c|}
\hline No butir & $1 \mathrm{a}(\mathrm{i})$ & $1 \mathrm{a}(\mathrm{ii})$ & $1 \mathrm{a}(\mathrm{iii})$ & $1 \mathrm{a}(\mathrm{iv})$ & $1 \mathrm{a}(\mathrm{v})$ & $1 \mathrm{a}(\mathrm{vi})$ & $1 \mathrm{a}(\mathrm{vii})$ & $1 \mathrm{a}$ (viii) & $1 \mathrm{a}(\mathrm{ix})$ \\
\hline Pembagian & $108: 4$ & $\frac{1}{2}: 3$ & $\frac{1}{2}: \frac{1}{4}$ & $\frac{1}{3}: \frac{1}{5}$ & $4: \frac{1}{3}$ & $5: 7$ & $\frac{1}{4}: \frac{1}{2}$ & $\frac{1}{5}: \frac{1}{2}$ & $1 \frac{1}{2}: \frac{1}{3}$ \\
\hline $\begin{array}{c}\text { Rata-rata } \\
\text { skor Pretes }\end{array}$ & 4,5 & 3,675 & 2,75 & 1,75 & 2,65 & 1,65 & 1,625 & 1,4 & 1.075 \\
\hline $\begin{array}{c}\text { Rata-rata } \\
\text { skor Postes }\end{array}$ & 8,5 & 5,95 & 6,65 & 3,83 & 5,55 & 3,33 & 4,3 & 3,1 & 2,25 \\
\hline
\end{tabular}

Berdasarkan skor pada Tabel 5, skor Postes selalu lebih tinggi dari pada skor Pretes. Walaupun setelah dilakukan pembelajaran melakukan pembagian dengan diagram skematik Vergnaud, masih tetap rata-rata skor masih dibawah pencapaian $50 \%$, tetapi peningkatan pemahaman sudah tampak. Peningkatan itu tampak dari rata-rata dari skor Pretes adalah 2,341 dengan varians 1,316, sementara rata-rata dari skor Postes adalah 4,82 dengan varians 3,97. Menggunakan uji beda rataan, diperoleh terdapat perbedaan yang signifikan. Urutan tingkat kesukaran pembagian berdasarkan jenis bilangan masih konsisten seperti pemahaman sebelum dibelajarkan diagram skematik Vergnaud. Kemampuan subjek mengajukan soal cerita pada pembagian sebelum dan sesudah diberikan pembelajaran pada subjek disajikan pada Tabel 6 berikut.

Tabel 6: Skor dan Frekuensi Pretes dan Postes kemampuan mengajukan soal cerita

\begin{tabular}{|c|c|c|c|c|c|c|c|c|c|}
\hline No butir & $\mathbf{1 d}(\mathbf{i})$ & $\mathbf{1 d}(\mathbf{i i})$ & $\mathbf{1 d}(\mathbf{i i i})$ & $\mathbf{1 d}(\mathbf{i v )}$ & $\mathbf{1 d}(\mathbf{v})$ & $\mathbf{1 d}(\mathbf{v i})$ & $\mathbf{1 d}(\mathbf{v i i})$ & $\mathbf{1 d}(\mathbf{v i i i})$ & $\mathbf{1 d ( i x )}$ \\
\hline Pembagian & $108: 4$ & $\frac{1}{2}: 3$ & $\frac{1}{2}: \frac{1}{4}$ & $\frac{1}{3}: \frac{1}{5}$ & $4: \frac{1}{3}$ & $5: 7$ & $\frac{1}{4}: \frac{1}{2}$ & $\frac{1}{5}: \frac{1}{2}$ & $1 \frac{1}{2}: \frac{1}{3}$ \\
\hline $\begin{array}{c}\text { Rata-rata } \\
\text { skor Pretes }\end{array}$ & 8,075 & 5,85 & 1,025 & 0,3 & 0,88 & 3,5 & 0,3 & 0,225 & 0,325 \\
\hline $\begin{array}{c}\text { Frekuensi } \\
\text { menjawab } \\
\text { benar } \\
\text { Pretes }\end{array}$ & $\begin{array}{c}80 \% \\
(32)\end{array}$ & $\begin{array}{c}52,5 \% \\
(21)\end{array}$ & $\begin{array}{c}0,03 \% \\
(1)\end{array}$ & $\begin{array}{c}0 \% \\
(0)\end{array}$ & $\begin{array}{c}0,05 \% \\
(2)\end{array}$ & $\begin{array}{c}0,35 \% \\
(14)\end{array}$ & $\begin{array}{c}0,03 \% \\
(1)\end{array}$ & $\begin{array}{c}0 \% \\
(0)\end{array}$ & $\begin{array}{c}0,03 \% \\
(1)\end{array}$ \\
\hline $\begin{array}{c}\text { Rata-rata } \\
\text { skor Postes }\end{array}$ & 8,1 & 6,25 & 2,9 & 0,7 & 3,38 & 4,05 & 0,85 & 0,45 & 1,05 \\
\hline $\begin{array}{c}\text { Frekuensi } \\
\text { menjawab } \\
\text { benar } \\
\text { Postes }\end{array}$ & $74 \%$ & $57 \%$ & $0,25 \%$ & $0,05 \%$ & $26 \%$ & $36 \%$ & $0,05 \%$ & $0,03 \%$ & $0,05 \%$ \\
$(10)$ & $(24)$ & $(12)$ & $(15)$ & $(2)$ & $(1)$ & $(2)$ \\
\hline
\end{tabular}

Berdasarkan skor pada Tabel 6, skor dan frekuensi menjawab benar selalu lebih tinggi dari pada skor postes dari pada pretes. Walaupun setelah dilakukan pembelajaran melakukan pembagian dengan diagram skematik Vergnaud, masih 


\section{Pengetahuan Mahasiwa Calon Guru Pada Pembagian Pecahan}

tetap rata-rata skor masih dibawah pencapaian $50 \%$, kecuali pada pembagian bilangan asli dan pembagian pecahan dengan bilangan asli. Tetapi peningkatan pemahaman sudah tampak setelah diberi pembelajaran diagram skematik Vergnaud. Peningkatan itu tampak dari rata-rata dari skor Pretes adalah 2,275 dengan varians 8,404, sementara rata-rata dari skor Postes adalah 3,08 dengan varians 3,25. Menggunakan uji beda rataan, diperoleh terdapat perbedaan yang signifikan. Urutan tingkat kesukaran pembagian berdasarkan jenis bilangan masih konsisten seperti pemahaman sebelum dibelajarkan diagram skematik Vergnaud, yakni mengajukan soal cerita dengan model matematika pembagian bilangan asli degan konteks gaji, dan tersulit adalah pembagian pecahan satuan dengan pecahan satuan yang penyebutnya bilangan ganjil. Kemampuan subjek menyelesaikan soal cerita sebelum dan sesudah dilakukan pembelajaran pembagian dengan diagram skematik Vergnaud disajikan pada Tabel 7.

Berdasarkan skor pada Tabel 7, skor kemampuan menyelesaikan soal cerita untuk pembagian selalu lebih tinggi skor postes dari pada pretes. Kemampuan subjek menyelesaikan pembagian soal cerita setelah diberikan pembelajaran melakukan pembagian dengan diagram skematik Vergnaud, sudah lebih dari 50\%. Kecuali pada kemampuan penjumlahan maupun perbandingan berbalik nilai, masih kurang dari $50 \%$.

Tabel 7: Skor Pretes dan Postes Kemampuan menyelesaikan soal cerita

\begin{tabular}{|c|c|c|c|c|c|c|c|}
\hline $\begin{array}{c}\text { Jenis } \\
\text { soal }\end{array}$ & $\begin{array}{c}\text { Pembagian } \\
\text { bilangan } \\
\text { asli konteks } \\
\text { gaji }\end{array}$ & $\begin{array}{c}\text { Pembagian } \\
\text { pecahan } \\
\text { dengan } \\
\text { pecahan } \\
\text { satuan }\end{array}$ & $\begin{array}{c}\text { Pembagian } \\
\text { pecahan } \\
\text { campuran }\end{array}$ & $\begin{array}{c}\text { Pembagian } \\
\text { bilangan asli } \\
\text { konteks } \\
\text { kecepatan }\end{array}$ & $\begin{array}{c}\text { Pembagian } \\
\text { pecahan } \\
\text { non satuan }\end{array}$ & $\begin{array}{c}\text { Penjumlahan } \\
\text { non } \\
\text { pembagian }\end{array}$ & $\begin{array}{c}\text { Perbandi } \\
\text { ngan } \\
\text { berbalik } \\
\text { nilai }\end{array}$ \\
\hline No soal & $2 \mathrm{a}, 2 \mathrm{~b}$ & $\begin{array}{c}3 \mathrm{a}, 3 \mathrm{~b}, 4 \mathrm{a}, \\
4 \mathrm{~b}\end{array}$ & $5 \mathrm{a}, 5 \mathrm{~b}$ & $6 \mathrm{a}, 6 \mathrm{~b}, 6 \mathrm{c}$ & $7,8,9$ & $10,11,13$ & 12,16 \\
\hline $\begin{array}{c}\text { Rata- } \\
\text { rata skor } \\
\text { Pretes }\end{array}$ & 8,5 & 6 & 3,1 & 6,5 & 3,7 & 1,4 & 1,1 \\
\hline $\begin{array}{c}\text { Rata- } \\
\text { rata skor } \\
\text { Postes }\end{array}$ & 9 & 8,6 & 5,2 & 8,7 & 5,1 & 1,4 & 1,6 \\
\hline
\end{tabular}

Kelemahan ini karena subjek menganggap soal itu sebagai pembagian, sehingga menyelesaikan dengan pembagian juga. Peningkatan menyelesaikan soal cerita tampak dari rata-rata dari skor Pretes adalah 4,33 dengan varians 7,63, 
sementara rata-rata dari skor postes adalah 5,66 dengan varians 10,69. Menggunakan uji beda rataan, diperoleh terdapat perbedaan yang signifikan. Urutan tingkat kesukaran pembagian berdasarkan jenis bilangan masih konsisten seperti pemahaman sebelum dibelajarkan diagram skematik Vergnaud, yakni yang termudah adalah menyelesaikan soal cerita pembagian bilangan bulat dengan konteks gaji dan dengan konteks kecepatan. Kemudian disusul dengan menyelesaikan pembagian dengan pecahan satuan bentuk 1/2, 1/3 1/4. Sedangkan menyelesaikan pembagian menyangkut pecahan non satuan dan pecahan campuran adalah yang tersulit diantara pembagian. Sebaliknya menyelesaikan soal cerita menyangkut penjumlahan dan perbandingan berbalik nilai masih tetap merasa kesulitan, hal ini tampak belum ada perobahan karena materi pembelajaran masih menyangkut pembagian.

Berdasarkan urutan tingkat kesulitan subjek pada pembagian, dapat dikaitkan dengan urutan penyajian pembagian dalam pembelajaran agar lebih dahulu membelajarkan pembagian yang termudah ke tersulit. Urutan itu adalah pembagian bilangan asli dengan bilangan asli, pembagian pecahan dengan bilangan asli, pembagian bilangan asli dengan pecahan, dan yang terakhir adalah pembagian pecahan dengan pecahan. Demikian juga pemahaman jenis pecahan juga mempunyai tingkat kesulitan yakni diawali dengan pecahan satuan $1 / 2$, pecahan satuan $1 / 4$, pecahan satuan $1 / \mathrm{n}$, $\mathrm{n}$ bilangan ganjil atau bukan 2 atau 4 , kemudian dilanjutkan dengan pecahan murni a/b. Hasil penelitian ini setara dengan hasil penelitian yang dilakukan oleh Rizvi dan Lawson (2007) menunjukkan hasil yang konsisten dengan penelitian ini. Pemahaman subjek menyelesaikan soal cerita pada pembagian tidak terbatas hanya pembagian partitif atau pengurangan berulang.

Pada penyelesaian soal cerita menyangkut pembagian, sebelum dikenalkan penyelesaian dengan menggunakan diagram skematik Vergnaud, banyak subjek menggunakan "perkalian silang" setelah membentuk model matematika dengan menuliskan persamaan. Setelah diperkenalkan alternatif pembagian dengan konsep rasio atau proporsional, subjek beralih menggunakannya dengan penalaran hubungan multiplikatif melalui diagram skematik Vergnaud. 


\section{SIMPULAN}

Hasil penelitian ini menunjukkan sebelum diperkenalkan penalaran multiplikatif melalui diagram skematik Vergnaud kepada mahasiswa calon guru, mereka belum memiliki pemahaman yang mencukupi dalam pembagian pecahan. Demikian juga pemahaman mahasiswa calon guru dalam pembagian pecahan masih diragukan untuk membantu siswa Sekolah Dasar memahami pembagian pecahan. Pernyataan ini ditunjukkan oleh data pemahaman mereka pada konsep pembagian pecahan, kemampuan mengajukan soal cerita menyangkut pembagian pecahan, dan menyelesaikan soal cerita pada pembagian pecahan. Setelah diperkenalkan penalaran multiplikatif melalui dengan diagram skematik Vergnaud, pemahaman mahsiswa calon guru dalam pembagian pecahan, mengajukan soal cerita menyangkut pembagian pecahan terjadi peningkatan. Secara khusus setelah diperkenalkan penalaran multiplikatif melalui dengan diagram skematik Vergnaud ditemukan bahwa kesulitan mahasiwa dalam menyelesaikan soal cerita pembagian pecahan sudah dapat teratasi.

\section{DAFTAR PUSTAKA}

Bulgar, S. (2009). “A Longitudinal Study of Students' Representations for Division of Fraction". The Montana Mathematics Enthusiast, Vol 6, Nos. 1 \& 2. pp. 165-200.

Cramer, K., Monson, D., Whitney, S., Leavitt, S., dan Wyberg, T. (2010). Dividing Fraction and Problem Solving: See how a class of sixth graders used concrete and pictorial models to build meaning for arithmetic operations with fractions. Mathematics Teaching in the Middle School. Vol 15 No.6. NCTM.

Downton, A. (2013). "Making Connections between Multiplication and Division". Proceeding of the $36^{\text {th }}$ annual conferency of the Mathematics Education Research Group of the Australasia. Melbourne VIC: MERGA. pp.242-249.

Kribs-Zaleta, C. (2006). “Invented Strategies fo Division of Fraction”. Proceedings of the $28^{\text {th }}$ Annual Meeting of North American Chapter of the International Group for the Psychology of Mathematics Education. Merida, Mexico: Universidad Pedadodica Nacional.

Ma, L. (1999). Knowing and Teaching Elementary Mathematics: Teacher' Understanding of Fundamental in China and the United States. Mahwah, New Jersey: Lawrence Erlbaum Associates.

Orrill, C. H. dan Jacobson, E. D. (2010). “Teachers' Emerging Understanding of Fractions Division as Proportional Reasoning in Professional Development". American Educational Research Association, San Diego. 
Pangaribuan, Firman. (2015). Profil abstraksi siswa yang bergaya kognitif reflektif dan siswa yang bergaya kognitif impulsif dalam pembagian pecahan. Disertasi Pascasarjana UNESA.

Rizvi, N.F.dan Lawson, M.J. (2007). "Prospective Teacher's Knowledge: Concept of Division”. International Educational Journal, Vol.8 No.2, pp.377-392.

Sharp, J., dan Adams, B. (2002). "Children's constructions of knowledge for fraction division after solving realistic problems". The Journal of Educational Research, Vol. 95 pp. 333-347.

Siswono, Tatag Yuli Eko. (2010). Penelitian Pendidikan Matematika. Surabaya: Unesa University Press.

Zembat, Ismail Ozgur. (2004). Conceptual Development of Prospective Elementary Teachers: The Case of Division of Fractions. Disertasi: Pennsylvania State University. 